\title{
Performance Evaluation of Weeder by Number of Blades per Flange in Maize Crop
}

\author{
B. Devojee*, S.S. Meena, A.K. Sharma and C. Agarwal \\ Department of Farm Machinery and Power Engineering, CTAE, Udaipur, India \\ *Corresponding author
}

\section{Keywords \\ Number of blades per flange, \\ Operational speed, \\ Actual field capacity, Weeding efficiency, Plant damage, Fuel consumption}

Article Info

Accepted:

17 March 2019

Available Online:

10 April 2019

\section{A B S T R A C T}

A weed is essentially any plant which grows where it is not required. A weed can be thought of as any plant growing in the wrong place at the wrong time and doing more harm than good. Weeds are the most severe and widespread biological constraint to crop production, and cause invisible damage till the crop is harvested. The composition and competition by weeds are dynamic and dependent on soil, climate, cropping and management factors. Weeds decrease the value of land, particularly perennial weeds, which tend to accumulate on long fallows; increase cost of cleaning. Significant portion of farmer's time is wasted for weeding of crops. Weeding is the removal of unwanted plants in the field crops. Mechanical weed control is very effective as it helps to reduce drudgery involved in manual weeding, it kills the weeds and also keeps the soil surface loose ensuring soil aeration and water intake capacity. Weeding is an important but equally labour intensive agricultural unit operation. There is an increasing interest in the use of mechanical intra-row weeders because of concern over environmental degradation and a growing demand for organically produced food. Today the agricultural sector requires non-chemical weed control that ensures food safety. Consumers demand high quality food products and pay special attention to food safety. A portable knapsack power weeder was developed with width of cut was $25 \mathrm{~cm}$ and tested in maize crop with number of blades per flange (2, 4 and 6). Operational speed, actual field capacity, field efficiency, weeding efficiency, plant damage, actual working depth of cut, fuel consumption, performance index of $(2,4,6$ blades per flange) was $0.42,0.38$ and $0.36 \mathrm{~m} / \mathrm{s}, 0.028,0.025$ and 0.023 ha/h, 74.6, 66.6 and 61.3 per cent, $84.7,87.9$ and 89.3 per cent, $4.28,3.43$ and 2.40 per cent, $3.36,3.83$ and $4.33 \mathrm{~cm}, 0.61,0.67$, and $0.70 \mathrm{l} / \mathrm{h}, 136,127$ and 120 .

\section{Introduction}

India is a vast country having agriculture sector as the backbone of its economy. India has total land acquisition of about 329 Mha out of which 166 Mha (Sahay, 2008) of land is under cultivation. Day by day Indian population growing, hence, it is required produce more food to demand of the growing population. This can be achieved by two ways they are either increasing the land under cultivation or by adopting the high farming technique which would increase the crop yield as per population demand. As it is not possible to increase the land under cultivation, another option is increase the crop yield. A 
weed is any plant which grows where it is unwanted or not required. Weeds waste excessive proportions of farmers' time, thereby acting as a brake on development. Weeding is one of the most important farm operations in crop production system. Weeding is an important but equally labour intensive agricultural unit operation. Weeding accounts for about $25 \%$ of the total labour requirement (900-1200 man hours/hectare) during a cultivation season (Yadav and Pund, 2007). Indian agriculture is dominated by small farmers, having small land holdings for cultivation. The average size of the land holding declined to 1.15 ha in 2010-11 from 2.30 ha in 1970-71, and absolute number of operational holdings increased from about 70 million to 121 million. If this trend continues, the average size of holding in India would be mere 0.68 ha in 2020 and would be further reduced to a low of 0.32 ha in 2030 . This is a very complex and serious problem. At a conservative estimate, an amount of Rs.100 billion is spent on weed management annually in India, in arable agriculture alone (Anonymous, 2011). In India, farmers mainly follow the weeding with small hand tools though chemical weeding is slowly becoming popular, in spite of it being costly. Use of herbicides will have residual effect and change in quality of soil and the chemicals used in weed killers cause damage to the environment and to the health of people who come into contact with them. Tractor operated weeding implements can save about 75 per cent time and 20 per cent cost as compared to bullock drawn methods. But there is uncovered headland and tractor hiring charges will be crucial input cost which may vary according to the season.

The rotary type weeder stirs the soil more accurately, disturb the weed root and remove them from soil. In addition this helps in keeping the soil in loose condition for proper aeration. The major advantage of rotary power weeder is power being used for rotary weeder blades requires less draft and improved field performance. Several weeders are available which run by tractor or power tiller, these are large in size cannot work for low inter row spaced crops.

\section{Materials and Methods}

\section{Components of weeder}

The portable knapsack power weeder has consists of following components. They are engine, Flexible drive shaft, handle, worm gear box, rotor shaft, flanges, blades, blade cover, and transportation wheels (Fig. 1-10).

\section{Specifications of developed portable knapsack power weeder}

\begin{tabular}{|c|c|c|}
\hline $\begin{array}{l}\text { S. } \\
\text { No. }\end{array}$ & Specification & Value \\
\hline 1 & $\begin{array}{l}\text { Number of engine } \\
\text { cylinder }\end{array}$ & 1 \\
\hline 2 & $\begin{array}{l}\text { Engine maximum } \\
\text { power at } 6500 \mathrm{rpm}\end{array}$ & $1.25 \mathrm{~kW}$ \\
\hline 3 & Weeding width & $25 \mathrm{~cm}$ \\
\hline 4 & $\begin{array}{l}\text { No. of Blades per } \\
\text { flange }\end{array}$ & $2,4,6$ \\
\hline 5 & Rotor speed & $185 \mathrm{rpm}$ \\
\hline 6 & Weeding depth & $3-5 \mathrm{~cm}$ \\
\hline 7 & Power transmission & $\begin{array}{l}\text { Lightweight } \\
\text { aluminum gear box }\end{array}$ \\
\hline 8 & Fuel tank capacity & $0.9 \mathrm{~L}$ \\
\hline 9 & Fuel & $\begin{array}{l}\text { Petrol mixed with } \\
\text { lubricating oil ( } 1 \text { liter } \\
\text { of petrol with } 30 \mathrm{ml} \\
\text { of oil) }\end{array}$ \\
\hline 10 & Material of blade & $\begin{array}{l}\text { Spring steel -L-type } \\
\text { blade }\end{array}$ \\
\hline 11 & Total weight & $11 \mathrm{~kg}$ \\
\hline
\end{tabular}

\section{Experimental details}

Power weeder with different numbers of blades were selected as treatments

$\left(\mathrm{T}_{1}\right)$ Power weeder - 2 blades per flange, all are at $180^{\circ}$ to each other 
$\left(\mathrm{T}_{2}\right)$ Power weeder - 4 blades per flange, all are at $90^{\circ}$ to each other

$\left(T_{3}\right)$ Power weeder -6 blades per flange, all are $60^{\circ}$ to each other

\section{Performance evaluation of portable knapsack power weeder}

After completion of the development of power weeder, the field experiments were conducted to evaluate the performance of the machine.

\section{Speed of operation}

The speed of operation was calculated by observing the distance traveled and the time taken as

$S=\frac{\mathrm{L}}{\mathrm{t}}$

Where,

$\mathrm{S}=$ Forward speed of operation, $\mathrm{m} / \mathrm{s}$

$\mathrm{L}=$ Distance traveled, $\mathrm{m}$

$\mathrm{t}=$ Time taken, $\mathrm{s}$

\section{Effective working depth of cut}

The depth of cut of the machine with different blades was measured in the field by measuring the depth of soil layer tilled by the blade in a row. The depth of the weeding was measured by measuring scale in different rows at different places. Average of 3 observations was taken as depth of weeding and expressed in $\mathrm{cm}$.

\section{Effective working width of cut}

The width of cut of the machine with different blades was measured in the field by measuring scale in different rows at different places.

\section{Theoretical field capacity}

Theoretical field capacity of the machine is the rate of field coverage of the machine that based on 100 percent of time at the rated speed and covering 100 per cent of its rated width. It is expressed as hectare per hour and determined as follows (Kepner et al., 1978)

Theoretical field capacity, ha $\mathrm{h}^{-1}=$ Width(m)x Speed $(\mathrm{km} / \mathrm{h})$

10

\section{Effective field capacity}

The effective field capacity of power weeder was computed by recording the area weeded during each trial run in a given time interval. It is dependent upon speed of operation. With the help of stopwatch, time was recorded for respective trial run along with area covered.

Effective field capacity, ha $\mathrm{h}^{-1}=$ Area covered (ha)

\section{Field efficiency}

Field efficiency is the ratio of effective field capacity to the theoretical field capacity, Expressed as percentage

Field efficiency, per cent =

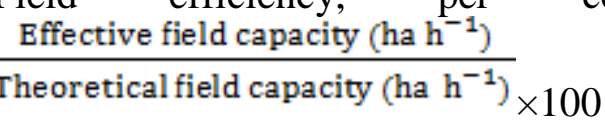

\section{Weeding efficiency}

Weeding efficiency is the ratio between the numbers of weeds removed by power weeder to the number of weeds present in a unit area and is expressed as a percentage. The samplings were done by quadrant method, by randomly selection of spots by a square quadrant of 1 square meter (Tajuddin, 2006). Higher the value of weeding efficiency better is the weeder performance. 
Weeding efficiency, per cent $=\frac{W_{1}-W_{2}}{W_{1}} \times 100$

Where,

$\mathrm{W}_{1}=$ Number of weeds counted in a unit area before weeding operation

$\mathrm{W}_{2}=$ Number of weeds counted in same unit area after weeding operation

\section{Plant damage}

Plant damage is the ratio of the number of plants damaged after operation in a row to the number of plants present in that row before operation. It was calculated by the following formula (Yadav and Pund, 2007). It is expressed in percentage.

Plant damage $(\%)=1-\frac{\mathrm{O}}{\mathrm{P}} \times 100$

Where,

$\mathrm{Q}=$ Number of plants in a $10 \mathrm{~m}$ row length of field after weeding

$\mathrm{P}=$ Number of plants in a $10 \mathrm{~m}$ row length of field before weeding

\section{Performance index}

Performance of the weeder was assessed through performance index (PI) by using the following relation as suggested by (Srinivas $e t$ al., 2010).

Performance index $=\frac{\text { FC } \times(100-P D) \times W E}{\text { Engine power }(\text { hp })}$

Where,

$\mathrm{FC}=$ Field capacity, ha $\mathrm{h}^{-1}$

$\mathrm{PD}=$ Plant damage, per cent

$\mathrm{WE}=$ Weeding efficiency, per cent

\section{Fuel consumption}

The fuel consumption has direct effect the economics of the power weeder. It was measured by top fill method. The fuel tank was filled to full capacity before and after the test. After completion of test operation, amount of fuel required to top fill again is the fuel consumption for the test duration. It was expressed in litre per hour.

Fuel consumption $=\frac{\text { Fuel consumption, } \mathbf{~}}{\text { Times } \text { hr }^{2}}$

\section{Instrumentations}

\section{Stop watch}

A stop watch was used to measure time required for one turn and turning of a weeder. Time was generally measured in second and further calculated to minutes and hours as per requirement.

\section{Measuring tape}

A measuring tape of $30 \mathrm{~m}$ was used for measuring and marking in the field. A steel foot rule was also used for measuring depth of operation, height of crop and height of weeds.

\section{Tachometer}

Mechanical tachometer was used to measure the rpm of rotor shaft.

\section{Results and Discussion}

\section{Speed of operation}

Speed of operation of the weeder with different blades $(2,4$, and 6$)$ was determined. Maximum and minimum speed of operation of the weeder was $0.42 \mathrm{~m} / \mathrm{s}$ with 2 blades and $0.36 \mathrm{~m} / \mathrm{s}$ with 6 blades, whereas $0.38 \mathrm{~m} / \mathrm{s}$ with 4 blades (Table 1).

\section{Effective working depth of cut}

The effective working depth of cut of weeder for different blades (2, 4, and 6) was 
determined. The data reveals that, the maximum and minimum depth of cut of weeder was $4.33 \mathrm{~cm}$ with 6 blades and 3.36 cm with 2 blades, whereas $3.83 \mathrm{~cm}$ with 4 blades.

\section{Effective working width of cut}

The width of cut of the weeder with different blades was measured in the field by observing the strip of soil and weeds cut in a row. The effective width of cut of the weeder was found as $25 \mathrm{~cm}$.

\section{Theoretical field capacity}

The theoretical field capacity of the weeder with different blades (2, 4, and 6) was measured. The width of cut of the weeder was $25 \mathrm{~cm}$ and speed of operation was assumed $1.5 \mathrm{~km} / \mathrm{h}$ for all blades (2, 4 and 6$)$. The theoretical field capacity of the weeder for all blades was $0.0375 \mathrm{ha} / \mathrm{h}$.

\section{Effective field capacity}

The effective field capacity of the weeder with different blades (2, 4, and 6) was measured. Higher the value of field capacity better was the weeder performance. The data reveals that, the maximum and minimum effective field capacity of weeder was 0.028 ha/h with 2 blades and $0.023 \mathrm{ha} / \mathrm{h}$ with 6 blades, whereas $0.025 \mathrm{ha} / \mathrm{h}$ with 4 blades.

\section{Field efficiency}

The field efficiency of the weeder with the different blades $(2,4$, and 6) was measured. The data reveal that the maximum and minimum field efficiency of weeder was 74.6 per cent with 2 blades and 61.3 per cent with 6 blades, whereas 66.6 per cent with 4 blades. The actual field capacity of weeder increases with increasing field efficiency and decreases with decreasing field efficiency.

\section{Weeding efficiency}

The weeding efficiency of the weeder with the different blades (2, 4, and 6) was measured. The data reveal that the maximum and minimum weeding efficiency of weeder was 89.3 per cent with 6 blades and 84.7 per cent with 2 blades, whereas 87.9 per cent with 4 blades. In 6 blades, depth of cut increases as speed of weeder reduces, weeding efficiency increases whereas comparing with 2 blades depth of cut decreases and speed increases, weeding efficiency decreases. Weeding efficiency depends on the number of weeds presents in the crop.

The power weeder has the capacity to till the weeder blade cut the soil to desired depth. Therefore, it works much better between two rows for control of weeds. The rotating blade of power weeder may cause damage to the plants if it is brought nearer to the rows. Considering this limitation of weeder, it gives lower weeding efficiency 89.3 percent. The power weeder gives better performance even in later stages of weeding. It was clear that, as the depth of operation increases, the weeding efficiency increases.

\section{Plant damage}

The plant damage of the weeder with the different blades (2, 4, and 6) was measured. The data reveal that the maximum and minimum weeding plant damage of weeder was 4.28 per cent with 2 blades and 2.4 per cent with 6 blades, whereas 3.43 per cent with 4 blades.

Maximum plant damage was observed with 2 blades as it runs with high speed and jerks. Comparing with 6 blades, rotor moving with low speed and depth of cut increases and no jercks was observed and thereby lower plant damage was observed. 
Table.1

\begin{tabular}{|c|c|c|c|c|}
\hline S.No & Parameter & 2 Blade & 4 Blade & 6 Blade \\
\hline $\mathbf{1}$ & Operational speed, (m/s) & 0.42 & 0.38 & 0.36 \\
\hline $\mathbf{2}$ & Actual field capacity, & 0.028 & 0.025 & 0.023 \\
\hline & (ha/h) & & & 61.3 \\
\hline $\mathbf{3}$ & Field efficiency, (\%) & 74.6 & 66.6 & 89.3 \\
\hline $\mathbf{4}$ & Weeding efficiency, $(\%)$ & 84.7 & 87.9 & 2.4 \\
\hline $\mathbf{5}$ & Plant damage, (\%) & 4.28 & 3.43 & 4.33 \\
\hline $\mathbf{6}$ & Actual working depth of & 3.36 & 3.83 & 0.70 \\
\hline $\mathbf{7}$ & cut, (cm) & & & 120 \\
\hline $\mathbf{8}$ & Fuel consumption, $(1 / \mathrm{h})$ & 0.61 & 0.67 & 127 \\
\hline
\end{tabular}

Fig.1 Portable knapsack power weeder

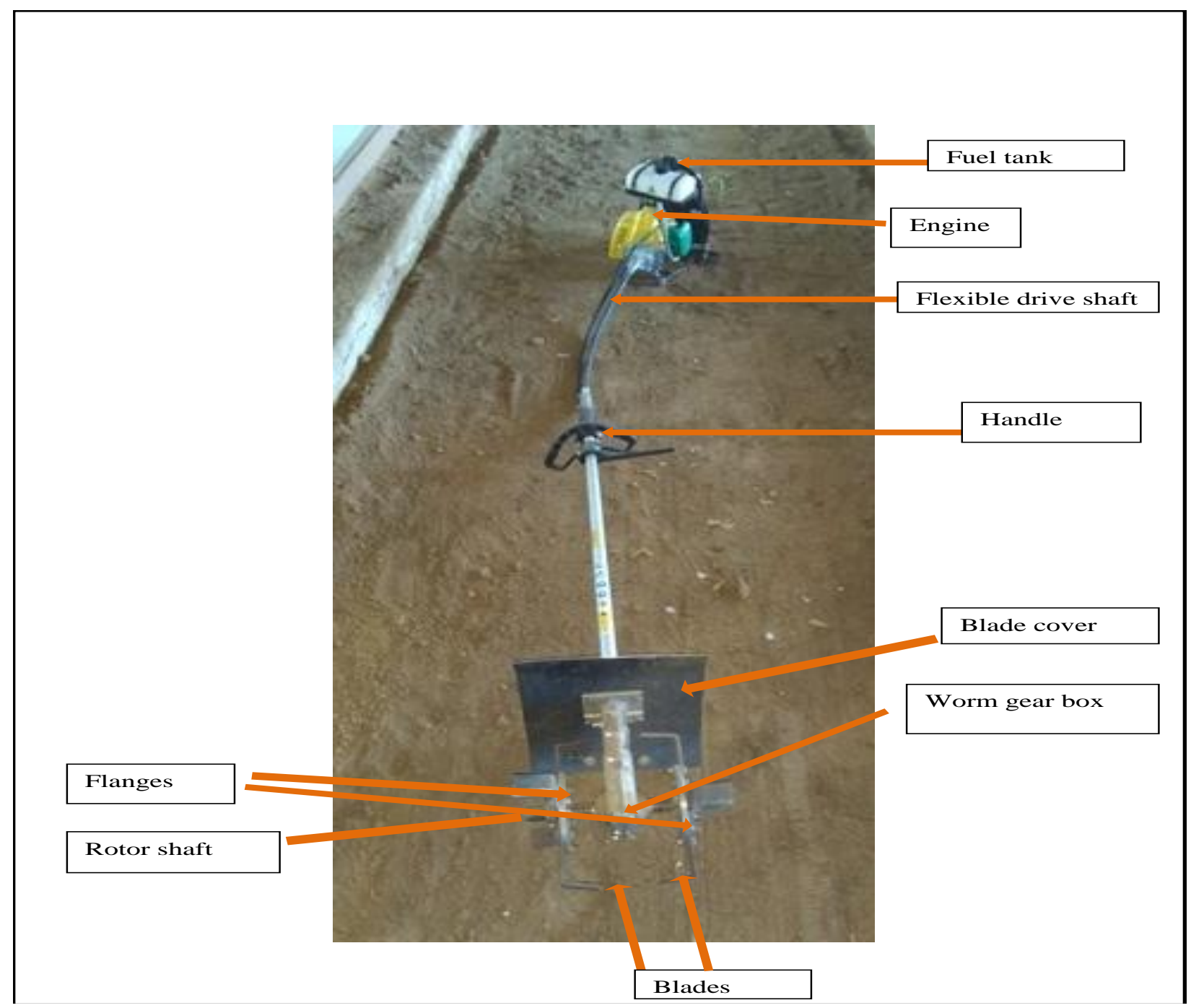


Fig.2 Flange with 2 blades

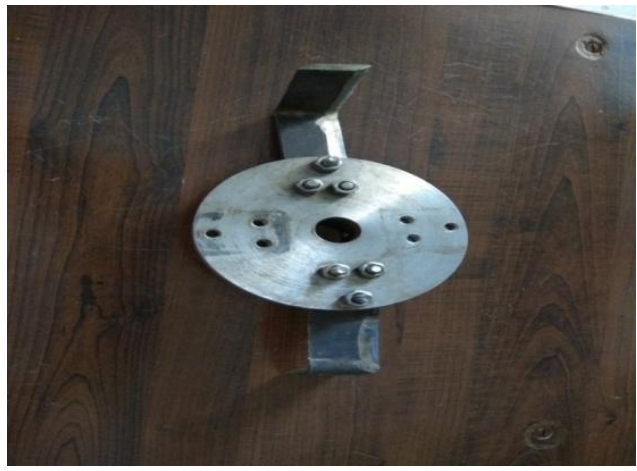

Fig.3 Flange with 4 blades

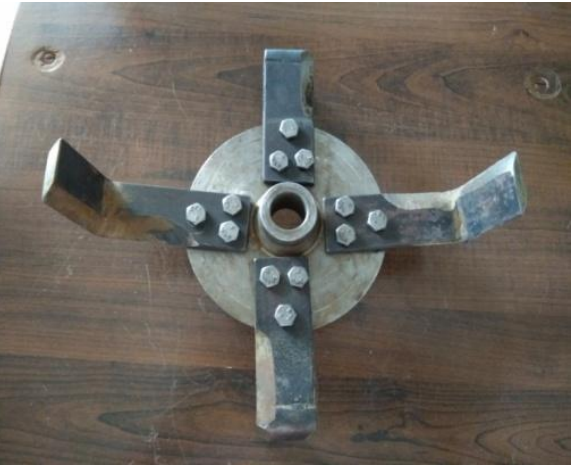

Fig.4 Flange with 6 blades

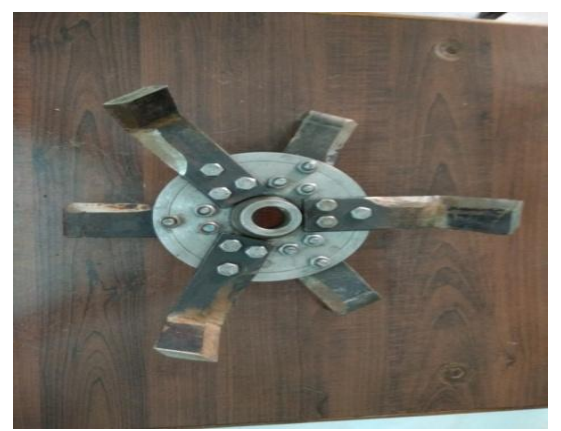

Fig.5 Measurement of depth of cut

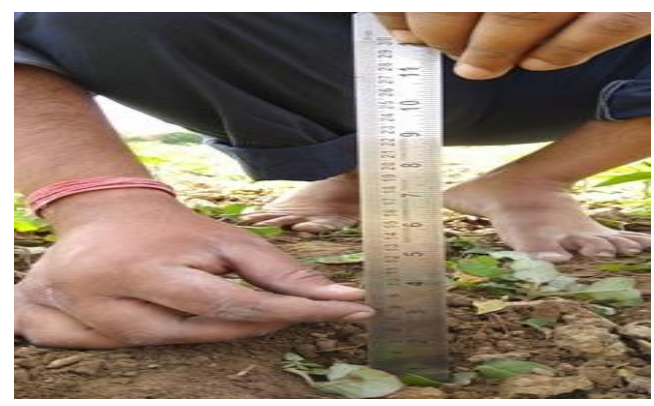

Fig.6 Measurement of width of cut

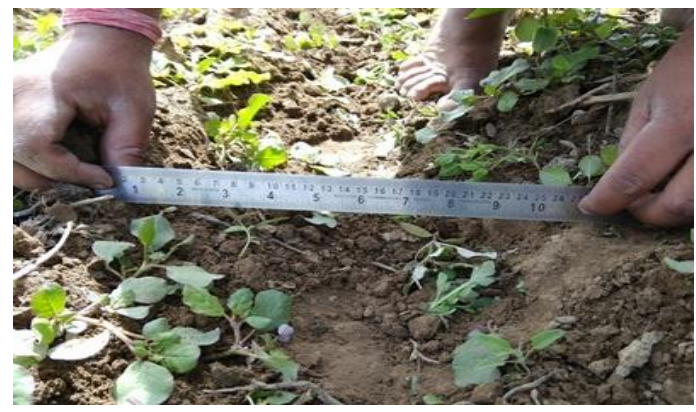


Fig.7 Measurement of fuel consumption

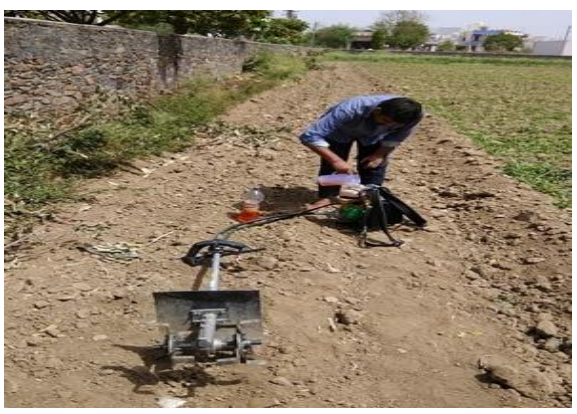

Fig.8 Testing in maize field

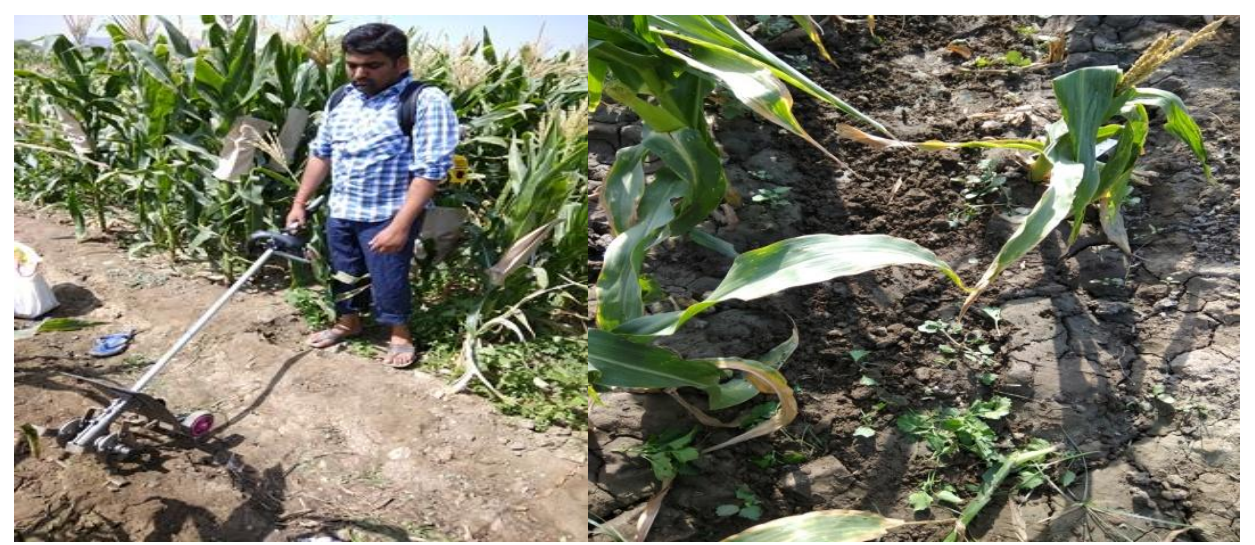

Fig.9 Measuring of row to row spacing

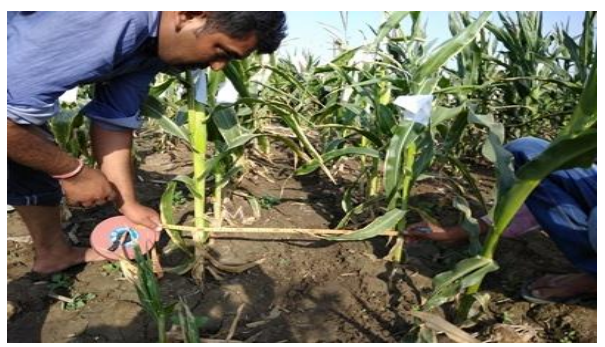

Fig.10 Measurement of rpm of rotor shaft with tachometer

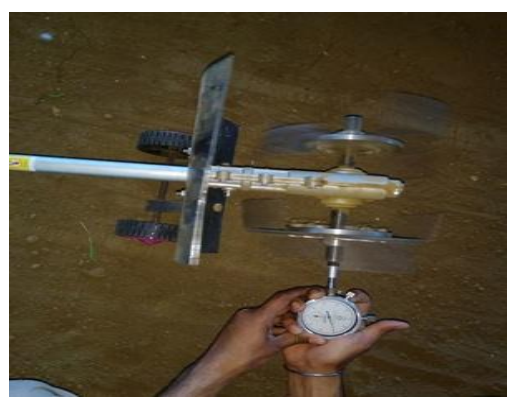




\section{Fuel consumption}

Fuel consumption of the power weeder was calculated by topping method. The maximum fuel consumption was found with 6 blades as $0.70 \mathrm{l} / \mathrm{h}$ due to more depth of cut $(4.33 \mathrm{~cm})$ and minimum fuel consumption was found in maize crop with 2 blades as $0.61 \mathrm{l} / \mathrm{h}$ due to low depth of cut $(3.36 \mathrm{~cm})$. Whereas with 4 blades the fuel consumption was $0.67 \mathrm{l} / \mathrm{h}$.

\section{Performance index}

Maximum and minimum performance index of power weeder was 136 with 2 blades and 120 with 6 blades respectively. Whereas with 4 blades the performance index was 127

In conclusion, the performance evaluation of weeder by number of blades per flange in maize crop was found satisfactory with 6 blades. The maize crop weeding efficiency was found 89.3 per cent and plant damage was observed as 2.4 per cent which was less compared to other types of blades. Fuel consumption was high in 6 blades which was $0.70 \mathrm{l} / \mathrm{h}$ in maize crop. From the study it can be concluded that the power weeder with 6 blades was preferred for weeding.

\section{References}

Ambujam, 1993. Evaluation of power weeder performance. Agricultural Mechanization in Asia, Africa and Latin America 24: 16.

Anonymous, 2011. Indian Council of Agricultural Research (Vision 2030).
Kepner, R.A., Bainer, R. and Barger, E. L. 1978. Principles of Farm Machinery, $3^{\text {rd }}$ edition, CBS Publications and Distributors, New Delhi.

Fanoll, 1993. Evaluation of power weeder performance. Agricultural Mechanization in Asia, Africa and Latin America 24: 16.

Kumar, N.T., Kumar, S. T., Madhusudan, N. A. and Ramya, V. 2014. Performance evaluation of weeders. International Journal of Science, Environment and Technology 3: 2160-2165.

Srinivas, I., Adake, R. V., Reddy, B. S., Korwar, G. R., Thyagaraj, C. R., Dange, A.,

Veeraprasad, G., and Reddy, R., 2010. Comparative performance of different

power weeders in rain fed sweet sorghum crop. Indian Journal of Dry land

Agriculture Research and Development 25: 63-67.

Rangasamy, K., Balasubramanian, M. and Swaminathan, K. R. 1993. Evaluation of power weeder performance. Agricultural Mechanization in Asia, Africa and Latin America 24: 16-18.

Tajuddin, A., 2006. Design, development and testing of engine operated weeder, Agricultural Engineering Today 30: 25-29.

Yadav, R., and Pund, S., 2007. Development and ergonomic evaluation of manual weeder. Agricultural Engineering International: The CIGR E Journal 9: $1-9$.

\section{How to cite this article:}

Devojee, B., S.S. Meena, A.K. Sharma and Agarwal, C. 2019. Performance Evaluation of Weeder by Number of Blades per Flange in Maize Crop. Int.J.Curr.Microbiol.App.Sci. 8(04): 2389-2397. doi: https://doi.org/10.20546/ijcmas.2019.804.278 